\title{
UNIVERSALITAS NILAI-NILAI ISLAM \\ Mengungkap Makna al-Din
}

\author{
Munzir Hitami \\ Guru Besar Fakultas Tarbiyah dan Keguruan UIN Sultan Suarif Kasim Riau \\ e-mail:mzr.hitami@gmail.com
}

\begin{abstract}
Abstrak
Konsep tentang Islam seringkali disalabfahami secara tekstual, tidak utuh. Al-Quran sendiri mensinyalir tentang betapa pentingnya memahami teks-teks itu secara menyelurub, tidak partikular, sebingga akan menemukan makna yang universal. Konsep-konsep tentang al-Din, al-Islam, dan lainnya, perlu dipahami sebagai sebuah teks yang tidak berdiri-sendiri, ia dirangkai sehingga melabirkan makna tertentu berdasarkan makna-makna relasionalnya. Kosakata jika ditempatkan secara berdiri sendiri tentu saja tidak akan menghasilkan makna yang utuh. Karena itu, semuanya ditata ke dalam suatu sistem relasi menyeluruh yang interdependen sehingga membentuk suatu keutuban yang tertata dalam jaringan asosiasi-asosiasi konseptual.
\end{abstract}

Kata kunci; Universalitas Islam, al-Din, Toleransi

\section{Pendahuluan}

Makna merupakan sebuah kata yang memiliki bidang wacana yang sangat luas dan melelahkan. Bila seorang berhadapan dengan suatu situasi di mana dia harus menangkap makna, maka dia berarti berhadapan dengan konsekuensikonsekuensi yang dapat menjerumuskannya ke dalam kancah perbincangan yang sengit. Makna dan pemahaman meskipun berbeda, namun tidak dapat dipisahkan. Dalam konteks perbincangan ini, makna dan pemahaman berkaitan dengan bahasa dan teks. Bahasa dan teks terdiri dari kosakata yang dirangkai sehingga melahirkan makna tertentu berdasarkan makna-makna relasionalnya. Kosakata jika ditempatkan secara berdiri sendiri tentu saja tidak akan menghasilkan makna yang utuh. Karena itu, semuanya ditata ke dalam suatu sistem relasi menyeluruh yang interdependen sehingga membentuk suatu keutuhan yang tertata dalam jaringan asosiasi-asosiasi konseptual.

Sejauh perhatian yang penulis curahkan, makalah ini hanya membicarakan term al-dìn yang digunakan al-Qur'ân. Di

29 I TOLERANSI: Media Komunikasi umat Beragama

Vol. 12, No. 1, Januari - Juni 2020 
sini, dalam hal makna kata dîn, pengintegrasian konsep-konsep atomistis, analisis tentang makna dasar dan makna relasional, perbandingan sistem-sistem konsep Arab pra-Islam, Yahudi-Kristen Arab pra-Islam, dan Al-Qur'an, serta analisis historis sinkronis dan diakronis, merupakan elemen-elemen yang semestinya mendapat perhatian. Setelah itu akan dikemukakan pula kendala-kendala yang selalu menghalangi munculnya pemahaman-pemahaman universalisme nilai-nilai Islam dan inklusivisme untuk terkungkung dalam pemahaman lokal dan eksklusivisme.

\section{Term al-Dîn dan Maknanya}

Term-term dînullâh, dînul-baqq dan addinul-qayyim merupakan ungkapan lain dalam Al-Qur'an yang menunjuk pada suatu kualifikasi ideal ke mana manusia diarahkan. Dari 92 kata dîn yang terdapat di dalam Al-Qur'an, lima kali di antaranya dengan redaksi dînullâh (dan dînih), empat kali dînul-haqq, dan enam kali dinul-qayyim termasuk dinul-qayyimah. Selain dari itu, kata ad-dîn sering dikaitkan dengan kata ikhlas (al-khâlish, al-mukhlishîn), yaitu pada dua tempat, dan dengan kata hanîf pada tiga ayat.

Kata din banyak digunakan dengan berbagai makna dan konteks. Kata yang terbentuk dari dâl-y $\hat{a}^{\prime}$-nûn ini mempunyai bermacam-macam arti yang antara satu dengan lainnya dapat dihubungakan, seperti, al- 'adah, ath-thâa ah, al-jazầ', al-bisâb dan al-qabru wal-isti lầ (AyhThabasyari,1986:26-27). Pada dasarnya, kata ad-din berarti suatu bentuk ketundukan dan perendahan diri atau jinsun minalinqiyâdi wadz-džull (Ibn Zakariya,1972).

Tunduk dan merendahkan diri dalam arti menundukkan diri kepada sesuatu yang lebih tinggi. Dari arti ini diturunkan arti-arti lainnya seperti telah disebutkan itu. Adat kebiasaan (al- âdat) disebut dîn karena manusia tunduk kepadanya dan mengikutinya secara terus-menerus. Hari pembalasan pada akhirat disebut yawmuddîn, sebab pada hari itu semua orang tunduk pada pengadilan Tuhan. Kekerasan dan penindasan (al-qahru wal-isti lầ) sebagai arti dari dîn karena berarti menundukkan dan merendahkan orang, dan bentuk kata din yang berarti hutang adalah karena orang berhutang itu merendahkan dirinya kepada orang yang tempat berhutang itu.

Dalam hubungannya dengan pembahasan di sini, kata dîn secara generik dimaksudkan sebagai ketundukan manusia terhadap sesuatu yang diyakininya, yang mana sesuatu itu lebih tinggi darinya. Maka dînullâh adalah ketundukan kepada Allah, dan dînul-haq adalah ketundukan kepada 
kebenaran. Perangkaian sebagian kata addìn yang disebutkan dalam Al-Qur'an dengan kata mukblish dan banîf menunjukkan pula kualifikasi ketundukan itu. Beberapa ayat di antaranya adalah: "Katakanlab! Sesunggubnya aku diperintabkan untuk menyembah Allah dengan ikblas karenaNya (dalam menjalankan) agama" (QS. azZumar, 39:11); 'Dia Yang Maha Hidup, tiada Tuban (yang berbak disembah) kecuali Dia, maka sembablah Dia dengan ikblas (dalam menjalankannya) agama" (QS. Ghâfir, 40:65); 'Dan (Aku perintabkan): Hadapkanlab wajahmu kepada agama dengan lurus" (QS. Yûnus, 10:105); "Maka hadapkanlah wajabmu kepada agama dengan lurus" (QS. arRûm, 30:30).

Redaksi kata ikhlâsh yang digunakan adalah khâlish, mukblish dan mukblishîn. Kata tersebut terbentuk dari huruf-huruf khâ'-lâm-shâd yang juga telah dipungut dalam bahasa Indonesia menjadi kata 'ikhlas'. Kata tersebut pada dasarnya berarti menyucikan sesuatu atau tanqiyatusy-syay'i wa tahd₹îbuh. Seperti diketahui, bahwa yang dimaksud menyucikan dengan kata tersebut adalah menyucikan niat dari segala yang memungkinkannya menjadi kotor, atau dengan kata lain yang biasa juga disebut sebagai 'ketulusan'.

Kata banîf lebih banyak dirangkaikan dengan kata millah dan Nabi Ibrâhîm, dan juga digandengkan dengan kata musliman. Kata hanîf berasal dari kata yang tersusun dari huruf-huruf $\underline{b} \hat{a}^{\prime}-n \hat{u} n-f \hat{a} '$ dalam bahasa Arab berarti al-mayl 'kecenderungan' dan albanîf berarti al-mâ'il 'yang cenderung'. Term baniff ini banyak mengundang perbedaan pendapat mengenai kepercayaan yang disebut hanîf tersebut sebelum Islam, terutama dalam kaitan ide tentang $\underline{b}$ anîf itu sebagai penganut agama Nabi Ibrâhîm.

Nabih Amin Farsi (1960:25) menyebutkan lima macam pendapat mengenai hanîff, yaitu 1) kelompok kepercayaan yang bukan Masehi dan bukan pula Yahudi; 2) bukan kelompok kepercayaan suatu agama dan tidak memiliki aturan agama tertentu; 3) gerakan kepercayaan Arab yang dipengaruhi oleh agama Masehi dan Yahudi; 4) gerakan kepercayaan Arab yang berdiri sendiri; dan 5) suatu kepercayaan yang mempunyai hubungan erat dengan kepercayaan ashShâbi'ah.

Nabih Amin Farsi (1960:34-37) sendiri mendukung pendapat yang terakhir dengan menyatakan bahwa kata banif dipungut melalui bahasa Arab pra-Islam dari bahasa Nabatean (an-Nabath). Argumen yang dipergunakannya dikutip dari penulis-penulis seperti Littman, W.H. Waddington, dan lainnya yang menitikberatkan hubungan kepercayaan 
Nabat dengan kepercayaan Arab pra-Islam terutama dalam soal pelarangan meminum khamar yang terdapat pada ajaran Islam dan kepercayaan sebagian kaum Nabat tentang Tuhan Kebaikan yang tidak meminum Khamar.

Meskipun hubungan kepercayaan antara kaum Nabat dan Arab pra-Islam merupakan suatu kemungkinan dalam perbauran budaya yang terjadi pada masa itu, namun yang jelas Al-Qur'an menekankan kata banîf sebagai kepercayaan Nabi Ibrâhîm. Dari dua belas kali kata banîf disebut dalam Al-Qur'an, terdapat delapan kali dikaitkan dengan Nabi Ibrâhîm a.s. dan selain itu perintah kepada manusia agar menjadi hanîf (jamak: bunafâ). Dalam bahasa Arab pasca Al-Qur'an, kata al-banîf hanya dikenal dengan arti al-mayl. Transformasi makna kata tersebut sebagai kepercayaan yang monoteis, bertentangan dengan kata yang mirip dengan kata tersebut, yakni kata "hanpo" (plural: hampe) umpamanya dalam bahasa Siryani (Syriac) yang berarti "berhala" (Lewis, dkk, 1971). Kendati ada kemungkinan dalam perkembangan bahasa juga berasal usul sama karena memang bahasa-bahasa tersebut serumpun. 'Kecenderungan'

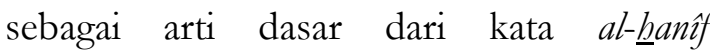
menunjuk pada kecenderungan dasar yang ada pada diri Nabi Ibrâhîm dengan melepaskan diri dari segala bentuk kungkungan tradisi dan lingkungan kehidupannya untuk mencari kebenaran. Kata hanîf dalam hal ini merupakan watak bawaan manusia yang cenderung kepada jalan lurus dan baik sebagaimana diungkapkan oleh Al-Qur'an melalui kasus Nabi Ibrâhîm tersebut: "Dan mereka berkata: 'Jadilah kamu penganut Yahudi atau Nasrani, niscaya kamu mendapat petunjuk', katakanlah: 'Tetapi (kami mengikuti) agama Ibrâhîm dengan lurus dan tidaklah ia termasuk orang-orang musyrik" (QS. al-Baqarah, 2:135); "Katakanlah! Tuhanku telah menunjuki aku kepada jalan yang lurus, (yaitu) agama yang benar, agama Ibrâhîm yang lurus dan tiadalah ia termasuk orang-orang musyrik" (QS. al-An`âm, 6:161).

Sehubungan dengan hal tersebut, maka kata ikhlâsh dan hanîf oleh Al-Qur'an dijadikan kualifikasi dari ad-dîn yang mempunyai arti dasar 'ketundukan'. Jika kata ad-dîn secara terminologis dapat diartikan sebagai bentuk-bentuk dan proses hubungan manusia dengan sesuatu yang lebih tinggi, maka intinya adalah ketundukan dan kepatuhan itu sebagai arti dasarnya. Bentuk dan proses tersebut biasa disebut dengan "agama" (Inggris: religion), sehingga kata dîn biasa diterjemahkan dengan agama. 
Di dalam Al-Qur'an, perangkaian kata ad-dîn yang paling penting adalah dengan kata al-Islâm pada ayat seperti yang terdapat dalam QS. Âlu 'Imrân, 3:19 dan 85; dan al-Mầidah, 5:3. Term al-Islâm, meskipun sudah amat dikenal, perlu dikemukakan mengingat penggunaan kata tersebut oleh Al-Qur'an menjangkau hal yang lebih luas. Dalam bentuk al-Islâm terdapat sebanyak delapan kali, bentuk muslim dua kali, bentuk muslimûn dan muslimin tiga puluh enam kali, bentuk muslimayn (tatsniyyah) satu kali, bentuk muslimah dan muslimât masing-masing satu dan dua kali, bentuk aslamâ, aslamtu, aslamtum, aslamnâ, aslamû, aslama (kata kerja bentuk lampau) seluruhnya empat belas kali, bentuk aslim dan aslimû (bentuk perintah) semuanya tiga kali dan bentuk kata kerja imperfect (yuslim, uslima, nuslima, tuslimûna, yuslimûna) masing-masing satu kali, serta bentuk as-silm satu kali. Beberapa di antara bentuk-bentuk kata tersebut digunakan untuk Nabi Ibrâhîm dan anak cucunya seperti dalam QS. al-Baqarah, 2:128, 131, 132, dan 133; Âlu `Imrân, 3:67; dan al-An`âm, 6:163. Kata-kata tersebut juga digunakan secara eksplisit untuk umatumat pada masa lampau yang beriman (QS.

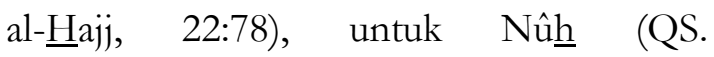
Yûnus,10:72), untuk para nabi yang berhukum kepada Taurat (QS. al-Mầidah,
5:44), untuk Ratu Saba' dan rakyatnya (QS. an-Naml, 28:31, 38, 42, dan 44), untuk umat Nabi Mûsâ dan tukang sihir Fir'aun yang beriman (QS. Yûnus, 10:84 dan alA'raf, 7:126), untuk Nabi Yûsuf (QS. Yûsuf, 12:101), dan untuk murid-murid

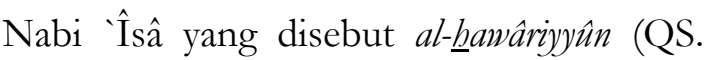
Âlu 'Imrân, 3:52), bahkan untuk semua yang ada di langit dan di bumi (QS. Âlu 'Imrân, 3:83).

Kata al-Islâm (aslama-yuslimu-islâman) berasal dari kata yang tersusun dari huruf sin-lâm-mîm menjadi salima yang pada dasarnya berarti ash-shibhah wal-âfiyah 'sehat' dan 'bugar'. Kata al-Islâm diartikan dengan al-inqiyâd karena arti tersebut menunjukkan bebas (dalam arti) sehat dari keengganan dan pembangkangan, atau yang diartikan juga sebagai 'tunduk'.

Ath-Thabâtabâ'iy mengartikannya sama dengan arti kata at-taslîmu wal-istislâm 'penyerahan diri'. Sepintas terlihat bahwa para mufasir bervariasi dalam menjelaskan makna al-Islâm. Dalam hal ini ada sebuah disertai dari Jane I. Smith yang mengadakan studi tentang makna term alIslâm tersebut sejauh penafsiran para mufasir mulai dari mufasir klasik sampai kepada mufasir modern. Studinya difokuskan pada kata al-Islâm terutama yang terdapat dalam QS. Âlu 'Imrân, 3:19: innad-dîna indallâbil-Islâm. Dalam studinya 
tersebut, ia menemukan 1) bahwa studinya tidak signifikan terhadap perbedaanperbedaan sektarian. Pola-pola yang terbukti dari studinya tidak berdasarkan afiliasi doktrinal atau geografis; 2) bahwa pada tingkat Islam individual sebagai sisi internal dan/atau eksternal, termasuk bidang hubungan respon manusia terhadap tindakan dan wujud Tuhan, semuanya tidak signifikan dan tidak berhubungan dengan waktu. Kemungkinan pengecualian adalah Sayyid Quthb yang mungkin tidak menekankan aspek tersebut karena perhatiannya tertuju pada organisasi komunal; 3) bahwa pada tingkat hubungan individu dan kelompok terdapat beberapa perubahan yang signifikan dalam hal cara bagaimana term Islam digunakan yang secara spesifik berhubungan dengan waktu tertentu.

Dalam tafsir-tafsir tradisional, Islam merupakan ketaatan individual sekaligus nama kelompok, tetapi penekanannya terutama pada yang pertama dan penggunaan ganda hanya ditunjukkan secara tersirat. Pada abad keempat belas/dua belas, term Islam digunakan (paling tidak) dalam dua cara yang berbeda, dalam tafsir baik al-Manâr maupun Sayyid Quthb dan yang terakhir ini aspek komunal mendapat penekanan utama (Smith, 175:232).
Dalam keanekaan definisi yang diberikan oleh para mufasir terhadap term al-Islâm itu, akhirnya Jane I. Smith menyimpulkan adanya benang kontinuitas yang kokoh selama empat belas abad yang tetap dipegang di balik keanekaan tersebut. Dengan mengutip sebuah hadis yang diriwayatkan oleh Imâm Anhmad: 'Islam mulai sebagai satu pokok, lalu berdahan, dan kemudian tumbuh bercabang-cabang," ia menemukan pokok tersebut bahwa Islam adalah pengakuan dan respon terhadap hakikat dan kehendak Tuhan. Apakah terlihat sebagai kepatuhan individual dari hamba dengan penerimaan hati dan anggota badan, atau sebagai komunitas yang terbuka terhadap semua orang yang disatukan dalam cinta dan damai, Islam adalah satu-satunya Din yang diterima Tuhan karena hanya Islam itulah agama milik-Nya (Smith, 175:234).

Dari penggunaan kata al-Islâm dan berbagai bentuknya yang lain dalam AlQur'an dalam berbagai konteks dan redaksinya semuanya menunjukkan ketundukan dan penyerahan diri kepada Tuhan secara ikhlas dan bersih dari nodanoda kufur dan syirik yang ketundukan dan penyerahan diri itu diaktualisasikan sesuai dengan ajaran nabi dan rasul dari masingmasing umat. Islam merupakan aktualisasi dari ketundukan yang murni (ad-dîn) dan 
ikhlas kepada Allah (al-ikblâsh) maka sebagaimana al-banîf (kecenderungan dasar manusia yang lurus), merupakan aktualisasi dari al-fithrah (esensi penciptaan yang bersih dan baik), demikian pula al-Islâm merupakan aktualisasi dari ad-dîn. Aktualisasi ini yang biasa terbentuk dalam suatu pranata yang disebut syariat yang terwujud dalam bentuk tindakan-tindakan nyata dicirikan oleh Al-Qur'an dengan kualifikasi-kualifikasi tertentu.

Kualifikasi pertama adalah ash-shalâb dalam rangkaian al-amalush-shâlih yang terdapat pada sembilan puluh empat tempat dalam berbagai redaksinya, dan ada satu kali dengan ungkapan 'amal ghayr shâlih. Dalam kaitan ini kata ash-shalâh (shalaba-yashluhu) merupakan kualifikasi tindakan dan perbuatan pada umumnya. Selain itu, banyak kata yang berakar dari kata ash-shalâh itu (shalaba, ashlabaa) disebutkan tanpa dirangkaikan dengan kata 'amala yang disebutkan pada delapan puluh satu tempat dengan berbagai bentuknya, tidak termasuk kata shâlih sebagai nama Nabi Shâlih a.s.

Kata ash-shalâh, seperti telah disinggung sebelumnya, yang terbentuk dari huruf shâd-lâm-bâa' tersebut adalah antonim dari kata al-fasâd 'kerusakan'. Secara etimologis, kata ash-shalâh berarti allayâqah yakni 'kelayakan', atau keadaan yang pantas, seimbang, dan normal (AthThabatabaiy, 1974;303). Sesuatu yang keluar dari keadaan yang layak, seimbang dan normal, itulah yang disebut rusak atau fâsid. Perbuatan memperbaiki sesuatu yang rusak disebut ishlâh, karena perbuatan tersebut mengembalikannya kepada keadaan yang layak dan normal seperti sediakala. Mendamaikan antara orang yang bermusuhan dikatakan juga ishlâh karena tindakan itu mengembalikan orang yang bermusuhan itu kepada keadaannya yang layak dan normal, sehingga kata ash-shulh berarti juga 'perdamaian'. Dalam penggunaan kata ash-shâlih dalam kaitannya dengan perbuatan manusia, Al-Qur'an membawakan sedikit tranformasi makna dari arti dasar seperti disebutkan di atas. Kata tersebut bukan saja berarti 'pantas' dan 'normal', tetapi juga berarti 'baik', yakni suatu kualifikasi normatif yang lebih dari sekedar kelayakan. Dalam hal ini, AlQur'an membuat antonim kata ash-shâlibât dengan as-sayyi'ât, umpamanya yang terdapat dalam QS. at-Tawbah, 9:102: "Dan (ada) orang-orang yang lainnya mengakui dosa-dosa mereka, mereka mencampurbaurkan pekerjaan yang baik dengan pekerjaan lain yang buruk. Mudah-mudahan Allah menerima taubat mereka. Sesunggubnya Allab Maha Pengampun lagi Maha Penyayang;" dan juga pada QS. alMu'min, 40:40: 'Barang siapa melakukan 
pekerjaan buruk, maka tidak akan dibalas kecuali balasan yang setimpal (dengan amal buruk itu), dan barang siapa yang mengerjakan pekerjaan yang saleh, baik laki-laki atau perempuan sedang ia beriman, maka mereka akan dimasukekan ke surga, di dalamnya mereka diberi rezeki dengan tiada terkira."

Kata sayyi'ah (jamak: sayyi'ât) berakar

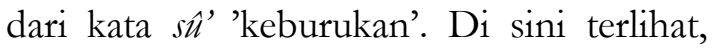
bahwa perubahan makna kata shâlih dari lâiq 'layak' kepada hasan 'baik' serta perubahan antonimnya dari fâsid 'rusak' menjadi sayy' 'buruk' adalah perubahan antara makna-makna yang masih berhubungan, karena sesuatu yang 'baik' umpamanya mestilah mengandung unsur kelayakan.

Transformasi makna tersebut merupakan transformasi dari bahasa deskriptif kepada bahasa normatif dengan tidak lepas dari makna dasarnya. Oleh sebab itu, seorang yang taat menjalankan ajaran Tuhan disebut sebagai orang saleh (ash-shâlih) selain karena secara normatif orang tersebut adalah orang baik, juga karena pada dasarnya orang tersebut dengan ketaatan tersebut berarti tetap pada jalan lurus sehinga ia tetap berada dalam keadaan yang layak dan terhindar dari kerusakan.

Sekarang beralih kepada kata basan (bentuk mujarrad) yang digunakan pada banyak tempat, yaitu mencapai seratus empat puluh tiga kali. Kata ini digunakan untuk berbagai konteks, baik yang bersifat material maupun yang bersifat spiritual. Makna yang lebih khusus dari kata tersebut dan yang dimaksudkan dalam pembahasan ini adalah kata basanah yang terdapat pada dua puluh delapan tempat ditambah tiga tempat dengan bentuk jamaknya, basanât. Antonim dari kata ini yang digunakan oleh Al-Qur'an juga kata sayyi'ah, seperti pernyataan-pernyataan ayat yang terdapat pada QS. Hûd, 11:114, dan ar-Ra`d, 13:6 dan 22.

Perubahan bentuk dari hasan menjadi hasanah merubah maknanya menjadi substantif, yakni sesuatu yang mempunyai kualitas yang ditunjuk oleh kata sifat tersebut dan biasa diartikan dengan jamâl, yakni 'bagus', 'indah', 'sempurna', 'baik' dan 'tidak ada cacat'. Kata ini digunakan secara luas dalam Al-Qur'an. Menurut arRâghib al-Asfahâniy (tt:117), kata basanah ini digunakan untuk menunjuk kebaikan dari sesuatu atau objek yang bersifat material ataupun immaterial seperti ungkapan wa'dan basanan 'janji yang baik' pada QS. Tâhâ, 20:87. Dari arti kata itu diturunkan juga arti kebahagiaan atau kesenangan seperti kata hasanah dalam QS. al-Baqarah, 2:201. Kata al-ihbsân mencapai lima puluh dua kali disebutkan dalam Al- 
Qur'an dengan berbagai bentuk redaksinya. Term ini merupakan salah satu term kunci dalam hal kualifikasi ideal perbuatan manusia. Nabi Muhammad saw. sendiri mendefinisikan term al-ihsân dalam sebuah hadis yang cukup terkenal: An ta’ budallâha ka'annaka tarâhu fa in lam takun tarâbu fa innabu yarâka (Bukhari, 1981:18), yakni yang intinya pengabdian kepada Allah seolah-olah seseorang itu berada di hadiratNya.

Dalam kaitan dengan hadis ini, Ibn Hajar al-Asqallâniy (tt:120) menjelaskan makna kata al-ihbsân dengan dua arti, yaitu al-itqân 'menghaluskan', 'menjadikan bagus dan sempurna', dan isshâlun-naf $i$ 'menyampaikan atau memberikan manfaat'. Kata al-ihssân dalam hadis tersebut menunjuk makna yang pertama itu, yakni menyempurnakan dan membaguskan ibadah atau sesuatu pekerjaan dengan ikhlas dan sungguh-sungguh seolah-olah berada di hadapan Allah. Di dalam AlQur'an, kata al-ihbsan dalam berbagai tempat mengacu kepada kedua makna tersebut.

Berikutnya kata al-birr yang terdapat dalam Al-Qur'an pada dua puluh tempat. Secara harfiah kata ini memiliki makna yang beragam seperti disebutkan oleh Ibn Fâris: kbilâful-baḅr, bikeâyatush-shawt, ashshidq, dan an-nabat. Zuhayr ibn Sulmâ menggunakan kata al-birr untuk menunjukkan penyembahan Tuhan.

Dalam Al-Qur'an kata tersebut berkaitan dengan ash-shidq yang berarti 'hal benar' (trueness) dengan perluasan arti sampai mencakup semua kebajikan sebagaimana tercermin dalam penggunaannya seperti yang terdapat dalam QS. al-Baqarah, 2:44, 177, dan 189; Âlu 'Imrân, 3:92; Maryam, 19:14 dan 32, dan juga sebagai salah satu nama-nama Allah yang baik (al-asmâ'ul-bisnâa) dalam QS. athThûr, 52:28. Sebagai contoh QS. alBaqarah, 2:177: "Bukanlah kebajikan menghadapkan wajahmu ke timur dan barat, tetapi kebajikan itu adalah siapa yang beriman kepada Allah, hari kemudian, malaikatmalaikat, al-kitab, nabi-nabi dan memberikan barta yang disukainya kepada kerabat, anakanak yatim, orang-orang miskin, musafir (yang terlantar), peminta-minta, dan hamba sahaya (untuk memerdekakan diri), serta mendirikan salat, membayar zakat, menepati janji bila berjanji, dan orang yang sabar dalam kesukaran dan penderitaan, dan ketika berperang; Mereka itulah yang benar, dan mereka itulah orang-orang yang bertakwa."

Dalam ayat tersebut terungkap apa yang dimaksud dengan term al-birr dan juga pada ayat-ayat yang disebutkan di atas yang dalam hal ini tampaknya term tersebut sama atau bersinonim dengan term al- 
‘malush-shâlith, kecuali dalam ayat yang dikutip itu ada penekanan pada arti dasar kata al-birr sebagaimana terungkap dengan pernyataan ulầikal-ladżina shadaqû.

Kata khayr merupakan term yang lebih komprehensif dalam mengungkapkan kualifikasi positif tentang perbuatan ataupun lainnya. Terdapat sebanyak 153 kali kata al-khayr disebutkan dalam AlQur'an dengan berbagai bentuk dan redaksinya, ditambah enam kali kata yang berakar dari kata yang terbentuk dari huruf-huruf $k h \hat{a}^{\prime}-y \hat{a}^{\prime}-r a a^{\prime}$ lainnya yang berarti 'memilih'. Arti dasar dari kata al-khayr adalah al-athfu wal-mayl yang maksudnya kecenderungan kepada sesuatu. Kata alkhayr diartikan sebagai 'kebajikan' (good) yang antonimnya adalah asy-syarr 'kejahatan' (evii) karena setiap orang cenderung kepadanya sehingga orang itu memilihnya. Ibn Katsîr menukilkan sebuah hadis yang diriwayatkan oleh Ibn Mardawaih dari Abû Ja'far al-Baqir bahwa Nabi menjelaskan makna kata ini: al-khayr: itbâ'ul-Qur'ân wassunnah, yakni kebajikan itu mengikuti AlQur'an dan sunnah.

Dalam konteks ini, makna al-khayr 'pilihan terbaik' mestilah ditentukan oleh Allah dan Rasul-Nya. Dalam Al-Qur'an, kata tersebut digunakan juga untuk menunjuk sesuatu yang bersifat material, seperti ungkapan bubbal-khayr yang terdapat pada QS. Shâd, 38:32 dan alÂAdiyât, 100:8, dan juga digunakan untuk menunjuk kualifikasi perbuatan atau amal seperti yang terdapat dalam QS. azZalzalah, 99:7 dan 8: "Siapa yang mengerjakan kebajikan seberat zarrab sekalipun, niscaya ia akan melihatnya, dan siapa yang mengerjakan kejabatan seberat zarrah sekalipun, niscaya ia akan melihatnya."

Term yang hampir sama dengan alkhayr adalah kata al-ma rûf yang dalam AlQur'an terdapat pada tiga puluh sembilan tempat dan dua kali kata al-`urf, tidak termasuk kata kerja yang berakar dari kata yang terbentuk dari 'ayn-râ'-fâ. Ada dua arti dasar dari kata tersebut, yakni yang pertama tatâbu 'usy-syay'i muttashilan ba`dlubu bi ba`dl dan yang kedua as-sukûnu wath-thama'nînah.

Yang pertama maksudnya perurutan sesuatu secara berangkai dan teratur antara satu dengan yang lainnya. Dengan cara ini dapat dikatakan bahwa sesuatu yang terjadi secara beruntut dan teratur sehingga dikenal dan familier bagi orang disebut dengan al-ma'rûf 'yang dikenal' atau 'familier'. Kata al- urf dengan arti 'adat' berhubungan dengan arti pertama ini, yakni sesuatu yang barlangsung secara teratur sampai menjadi kebiasaan. Lawan dari kata al-ma'rûf adalah kata al-munkar 'sesuatu yang tidak dikenal atau tidak familier'. Term al- ’urf dan al-ma`rûf dimaksudkan 
adalah kebajikan dalam kaitan arti pertama tersebut, yaitu mengacunya term tersebut pada ayat seperti khudril- afwa wa'mur bil'urfi wa'àidl 'anil-jâbilîn (QS. al-A `râf, 7:199) dan pernyataan al-amru bil-ma'rûfi wan-nabyu anil-munkar yang terdapat pada QS. Âlu 'Imrân, 3:104, 110, dan 114; alA râf, 7:157; at-Tawbah, 9:67, 71, dan 112; al- Haji, 22:41, serta ayat-ayat lain yang menggunakan term al-ma'ruf.

Berdasarkan makna ini dapat dibedakan antara kata al-khayr yang berarti kebajikan dalam kaitannya pada unsur 'pilihan' yang ditentukan oleh Allah dan rasul-Nya dengan kata al-ma'rûf yang berarti sesuatu yang dianggap baik oleh masyarakat. Dengan demikian, al-ma 'rûf dapat berkembang dan dikembangkan sejauh tidak bertentangan dengan al-khayr.

Term berikutnya adalah al- adl dan alqisth. Kata al-adl sendiri yang dibentuk pada dua puluh delapan tempat dengan berbagai bentuk dan redaksinya mempunyai dua arti asal yang konstradiksi, yaitu istiwâ' wa i wijajj 'lurus dan bengkok'. Kata yang terbentuk dari huruf-huruf 'ayndâl-lâm itu digunakan dalam Al-Qur'an dengan kedua arti tersebut, namun yang dimaksud di sini adalah kata al- adl dengan arti al-istiwấ. Berbuat adil terhadap sesuatu berarti berbuat lurus dalam arti tanpa menimbulkan kerugian atau memihak pada salah satu pihak dengan memberikan putusan atau perlakuan sama sesuai dengan ukuran atau takarannya. Kata al-qisth yang disebutkan dalam Al-Qur'an pada dua puluh lima tempat juga mempunyai dua arti dasar yang berlawanan. Kata al-qisth (dengan bacaan kasrah huruf awalnya) bersinonim dengan kata al-'adl. Kata kerja yang digunakan untuk makna tersebut adalah aqsatha-yuqsithu, sedangkan kata alqasth (dengan bacaan fathah huruf awalnya) berarti al-jûr 'kecurangan'.

Kedua kata yang bersinonim tersebut tercermin dalam penggunaannya pada beberapa ayat seperti dalam QS. an-Nisâ', 4:58: "... dan (Allah memerintahkanmu) apabila kamu memutuskan sesuatu hukum di antara manusia agar kamu memutuskan dengan adil. Sesungguhnya Allah memberikan pengajaran yang sebaikbaiknya kepadamu, sesungguhnya Allah Maha Mendengar lagi Maha Melihat.” Kemudian dalam QS. al-Mầidah, 5:42 dengan konteks yang sama dinyatakan: "... dan jika engkau memutuskan suatu hukum maka putuskanlah dengan adil, sesungguhnya Allah mencintai orang-orang yang berbuat adil." Pada kedua ayat ini terlihat kata al-adl dan al-qisth digunakan pada konteks pemberian putusan dengan adil yang hal itu menunjukkan bahwa kedua kata tersebut bersinonim. 
Term terakhir yang dikemukakan pada bagian ini adalah at-taqwâ. Kata ini merupakan bentuk tak beraturan yang unik. Kata at-taqwâ berasal dari kata yang terbentuk dari huruf-huruf wâw-qâf-yâ'. AthThabarsiy menyebutkan bahwa kata tersebut pada asalnya adalah waqwâ, kemudian huruf wâw yang di awalnya berganti dengan huruf tồ' sehingga menjadi taqwâ. Kata al-wiqâyah yang merupakan asal usul kata taqwâ itu berarti daf $u$ syay'in 'an syay'in bi ghayrih, yang maksudnya menolak atau menghindarkan sesuatu dengan menggunakan sesuatu yang lain.

Bentuk kata kerja dari kata tersebut yang digunakan dalam Al-Qur'an adalah ittaqâa-yattaqî. Dari berbagai definisi yang dikemukakan oleh para ulama dan mufasir dapat dikatakan bahwa at-taqwâ pada intinya adalah pemeliharaan diri dari segala hal yang dapat membawa kepada dosa atau maksiat sekecil apapun nilai dan bobotnya. Pemeliharaan diri yang dimaksud juga diungkapkan dengan kata 'takut' khasyyah, khawf, karena takut kepada sesuatu menyebabkan seseorang hati-hati dan berusaha untuk menghindarinya. Pemaknaan semacam itu diungkapkan sendiri oleh Al-Qur'an yang dapat dilihat pada beberapa ayat, antara lain dalam QS. al-Anbiyâ', 21:48-49: 'Dan sesunggubnya telah Kami berikan kepada Mûsâ dan Hârûn itu al-
Furqân dan cahaya serta pengajaran bagi orangorang yang bertakwa, yakni orang-orang yang takut kepada (azab) Tuban sedang mereka merasa takut akan (tibanya) hari kiamat;" QS. an-Nûr, 24:52: 'Dan barang siapa yang menaati Allah dan Rasul-Nya serta bertakwa kepada-Nya, mereka itulah orang-orang yang menang."

Dalam kaitan itu, ungkapan seperti ittaqullâha atau taqwallâh dimaksudkan memelihara diri dari siksa Allah, baik di dunia maupun pada hari kiamat dengan cara menjauhi segala larangan-Nya serta melaksanakan segala perintah-Nya. Makna seperti itu dari term at-taqwâ tersebut dalam berbagai ayat yang menggunakannya, seperti ayat-ayat yang terdapat dalam QS. al-Baqarah, 2:196 dan 203: "Dan bertakwalah kepada Allah, dan ketahuilah sesungguhnya Allah sangat keras siksaNya." "Dan bertakwalah kepada Allah dan ketahuilah sesungguhnya kamu akan dikumpulkan kepada-Nya;" dan ayat-ayat lainnya yang senada.

Keyakinan kepada hari kiamat beserta ganjaran bagi manusia atas segala keadaan dan tindakannya ketika hidup di dunia merupakan landasan bagi kualifikasi yang disebut at-taqwâ. Sebagaimana diketahui bahwa pertanggungjawaban eskatologis yang ditekankan oleh $\mathrm{Al}$ Qur'an ditentukan oleh tingkat keyakinan 
seseorang terhadap hari akhirat tersebut. Seseorang yang mempunyai keyakinan kuat terhadap hari akhirat, ia akan yakin akan mempertanggungjawabkan segala tindakannya di hadapan Allah pada hari itu. Dengan demikian, dapat dikatakan bahwa Al-Qur'an menekankan at-taqwâ sebagai sumber tindakan manusia yang berdasarkan keyakinan yang bertanggung jawab.

Sejauh ini telah dibicarakan berbagai term yang menunjuk pada kualifikasi- kualifikasi tertentu, baik yang menyangkut bentuk kepercayaan yang dimiliki oleh manusia sesuai dengan kecenderungan dasarnya maupun kualifikasi perbuatan atau tindakan sebagai manifestasi dan aktualisasi diri kecenderungan dasar tersebut. Dari semua yang telah dikemukakan barangkali untuk mengakhiri bagian ini di sini dapat dikemukakan pula suatu bentuk interrelasi dari term-term kunci yang telah diuraikan terdahulu sebagai berikut:

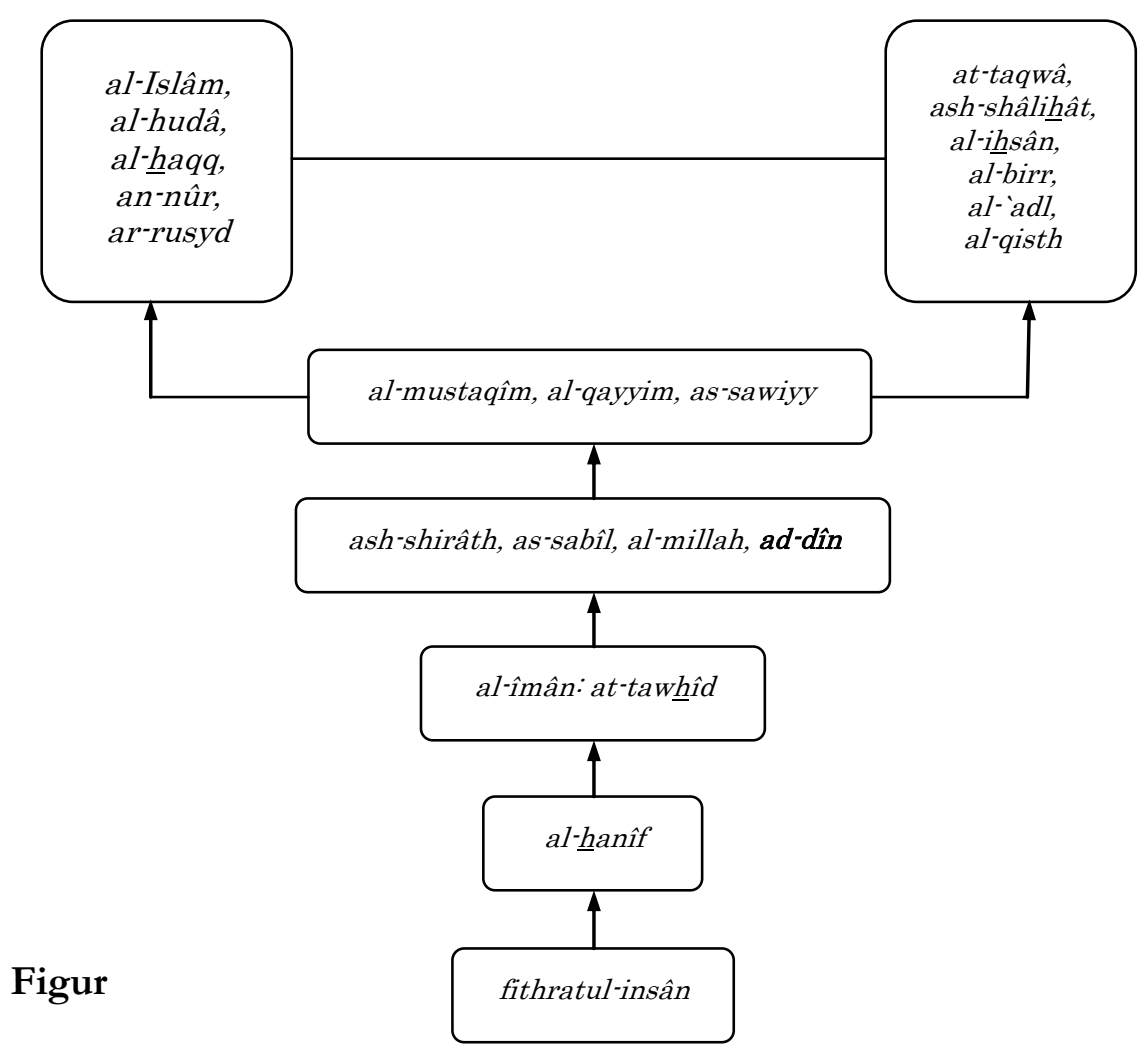

Dalam figur di atas tergambar bahwa muncul. Apakah kata Islâm itu hanya kata din merupakan sebuah konsep netral menunjuk kepada kualifikasi sebagaimana yang berbasis pada kepercayaan dan yang dijelaskan terdahulu? Pada kualifikasi-kualifikasi. Di antara kualifikasi kenyataannya term Islâm berkembang tersebut adalah Islâm. Di sini persoalan mulai menjadi suatu sistem kepercayaan. Lalu, apa 
yang dimaksud dengan Islâm? Apakah benar Islâm mengandung nilai-nilai yang universal? Kenapa nilai-nilai eksklusivisme menjadi begitu terdemonstrasi di dunia Islam?. Kalau di jawab bahwa Islâm itu adalah apa yang tertuang dalam al-Quran dan Sunnah Nabi, akan tetapi seperti apa dan menurut siapa? Al-Quran menyebut fầil dari kata Islâm sebagai Muslim. Pada kenyataannya al-Quran juga menggunakan istilah tersebut untuk menunjuk orang-orang atau komunitas sebelum kedatangan Nabi Muhammad, atau dengan kata lain ada orang atau komunitas di luar pengikut Nabi Muhammad yang dinamakan Muslim.

\section{Problem Pemahaman}

Jawaban dari pertanyaan-pertanyaan itu dalam sejarah wacana umat Islam sudah menimbulkan kontroversi-kontroversi yang begitu signifikan. Masalah universalisme dan lokalisme, eksklusivisme dan inklusivisme, absolutisme dan relativisme, dan lain sebagainya telah menjadi wacana yang hangat. Masing-masing pihak tidak jarang terjebak apologi yang berlebihan dengan menggunakan retorika sofistik. Hal ini terjadi karena adanya kendala-kendala pemahaman sebagai berikut:

Pertama, mental dogmatis. Mental dogmatis sifatnya adalah kaku dan tidak berubah serta anti kritik. Kekakuan tersebut sebenarnya wajar karena mental dogmatis sudah terbentuk sejak manusia masih kecil sampai dewasa. Kekakuan mental ( $\mathrm{La}$ rigidite mentale), adalah ketidak-mampuan seseorang mengubah perangkat pikiran atau mentalnya ketika dituntut persyaratan objektivitas, termasuk ketidaksanggupannya menyediakan kerangka atau ruangan yang berisi multi-alternatif bagi pemecahan satu masalah agar masalah itu dapat dipecahkan dengan seefektif-efektifnya (Deconchy, 1970). Dalam hal ini ada macam spirit (ruh), yakni spirit terbuka dan spirit tertutup berikut struktur bangunan masingmasing serta keterkaitan yang terakhir tersebut dengan mental dogmatisme dengan menekankan tingkat keterkaitan mental dogmatisme dengan system ideology tertentu.

Rokeach menggunakan istilah "Sistem aqidah" (Systeme de croyances) dan memandang mental dogmatis berpusat pada dikotomis ekstrim antara system iman atau aqidah dengan sisten non-iman atau non-aqidah. Dengan kata lain, bahwa mental dogmatis berkaitan dengan keketatannya yang kuat berpegang kepada seperangkat prinsip aqidah, dan menolak dengan keras perangkat lain yang di luarnya dan dianggap tidak berarti atau tidak berguna. Karena itu prinsip-prinsip aqidah itu merupakan kawasan terlarang bagi pemikiran rasional, atau bahkan mustahil dirasionalkan. 
Bila dipinjam istilah Rokeach ini, maka system iman dan non-iman tersebut dapat dibatasi pada hal-hal berikut: 1) merupakan gambaran dari suatu pengetahuan tertutup yang terbentuk dan berporos pada problem aqidah dan non-aqidah (Keyakinan penuh atau bukan keyakinan), 2) merupakan sesuatu yang berporos pada poros keyakinan penuh yang mempunyai kekhususan sendiri dan mutlak, dan 3) bahwa hal tersebut melahirkan serangkaian masalah toleransi atau intoleransi terhadap pihak lain (Deconchy, 1980).

Kemudian tingkat dogmatisme pandangan manusia dapat diukur dengan beberapa hal, antara lain:

1) Suatu struktur atau system pengetahuan tertentu menjadi dogmatis sejauh adanya tembok tebal yang membatasi antara system iman dan aqidah dengan system non-iman yang khusus baginya (Le beliefsystem/et les dis-belief-systems). Ada paling tidak empat cara bagi terwujudnya hal tersebut: memperkuat strategi di atas perbedaan-perbedaan yang ada antara system iman dan system non iman, b) pemapanan atas kondisi di mana tidak dibenarkan penghujatan-penghujatan yang dapat mencampur adukkan antara keduanya, c) menolak dengan keras kemudian meremehkan segala realitas yang kadang-kadang muncul bertentangan dengan aqidah tersebut, dan d) kemampuan untuk menerima berbagai kontradiksi di dalam system iman atau aqidah itu tanpa merasa adanya masalah apapun.

2) Suatu konstruksi pengetahuan dogmatis selalu memperlebar jurang pemisah antara kedua system yang bertentangan tersebut (dikotomi murni), yang tercermin pada upaya-upaya: a) penolakan terus menerus setiap upaya pendamaian atau penyelarasan di antara kedua system, b) keyakinan terus menerus dan bertambahtambah terhadap pengetahuan hakiki yang hanya dimiliki pihaknya, dan c) kemudian keyakinan yang kuat terhadap kebatilan system yang ada di luarnya.

3) Suatu konstruksi pengetahuan dogmatis menyama-ratakan segala system yang ditolaknya (pokoknya semuanya itu salah), yang benar hanya satu.

4) Suatu konstruksi pengetahuan dogmatis bila keyakinan-keyakinan pinggiran mesti bergantung kepada keyakinan sentral yang mendasar. Segala sesuatu yang pinggiran mesti diacukan dan disesuaikan dengan sentralnya dengan berbagai rasionalisasi atau justifikasi, sehingga seolah-olah tidak ada masalah dan terlihat kehebatan keyakinan sentralnya. 
5) Suatu struktur pengetahuan dogmatis bila perspektif dan visi kontemporernya selalu diarahkan kepada marcusuar masa lalu, yakni masa sekarang sangat tergantung kepada masa keemasan murni (konsep utopia). ${ }^{1}$

Kedua, mental mitis (mythic mental). Mental dogmatis sangat berkaitan dengan mental mitis ini. Pada masyarakat kuno penalaran imajiner lebih dominan daripada penalaran rasional sehingga segala sesuatu yang tak dapat dijelaskan secara rasional dapat dijelaskan dengan penalaran imajiner yang melahirkan mitos. Mitos adalah suatu bentuk kesadaran persepsi terintegrasi yang menyatukan fakta dan eksplanasi. Mitos berada pada tingkat kesadaran manusia yang belum mampu memilahkan antara fakta dan eksplanasi. Ia lebih merupakan mode persepsi atau visi daripada sebagai mode eksplanasi (Falk,1989).

Mitos merupakan bukti bahwa masalah-masalah krusial dalam hal-ihwal budaya manusia akan terekspresi dalam struktur mitos itu; dan konflik-konflik yang berstruktur dalam mitos tersebut akan memberikan informasi tentang masalahmasalah yang berstruktur pula yang ada dalam masyarakat. Namun mitos lebih merupakan ekspresi atau refleksi struktur

\footnotetext{
${ }^{1}$ Ibid
}

sosial yang tak tegas dan bersumber dari emosi yang terpendam dalam diri manusia. Mitos dapat memberikan alternatif-alternatif terhadap hal yang ada. Mitos biasanya berbentuk cerita atau dongeng. Sebuah dongeng tidak membentuk sebuah sistem logika yang konsisten sebagaimana cara yang dilakukan oleh agama. Dongeng sering berkaitan dengan yang ajaib dan absurd. Mitos memberikan perspektif yang sangat menarik mengenai agama karena mitos mengekspresikan hal ihwal agama pada tingkat yang tak terekspresikan. Analisis mitis (mythical analysis) memberikan perspektif penting mengenai struktur bawah sadar agama (unconscious structure of religion) (Oosten,1985).

Ketika mitos sudah menjadi dogma, maka segala macam pemahaman di luar pemahaman bersangkutan akan ditolak, karena pada gilirannya masuk ke dalam kawasan al-lâ mufakkear fîbi.

Ketiga, mental utopianisme. Mental ini sesungguhnya juga bersumber dari mental dogmatisme dan mitis yang pada prinsipnya menginginkan kehidupan masa kini wajib dibentuk sesuai dengan kehidupan masa lalu yang ideal. Mental utopianisme menjadi kendala untuk mengembangkan pemikiran kritis terhadap apa yang sudah diidealkan sehingga klaim dan doktrin-doktrinnya selalu 
dianggap mutlak. Umapamanya selalu terjadi bahwa pandangan terhadap sosok komunitas yang dicita-citakan sering ditandai dengan situasi yang selalu terjebak kepada perdebatan interpretative mengenai ajaran Islam itu sendiri. Bagaimana menghadirkan kembali sebuah komunitas yang pernah terbentuk lima belas abad yang lalu pada zaman sekarang ini? Sebagian orang secara $a$ priori menerima postulat bahwa Islam sesuai dengan segala zaman dan tempat dan apa yang sudah terbentuk pada zaman Nabi, dapat dihadirkan pada zaman sekarang secara murni. Sebagian lagi menyatakan bahwa berdasarkan realitas hukum alam (Sunnatullah) tentang perubahan, semua bentuk komunitas dan ajaran yang sudah terbentuk pada zaman yang lalu dapat dipahami dalam dan disesuaikan dengan konteks sekarang. Jadi perlu reinterpretasi terus-menerus sesuai dengan perjalanan zaman keadaan suatu tempat. Persoalannya sekarang adalah pilihan antara konteks masa lalu yang berarti kita kembali ke masa lalu, ataukah konteks masa kini yang menyiratkan makna bahwa kita mesti menyesuaikan pemahaman kita dengan masa kini.

Kendala-kendala tersebut dilengkapi oleh kendala-kendala lain berupa kendala yang lebih bersifat teknis seperti terdapatnya berbagai gap antara penganut agama dan agamanya. Dalam hal ini terdapat beberapa tingkat jurang yang menjadi masalah dan kendala bagi pemahaman sumber ajaran agama tersebut. Jurang pertama adalah antara teks ajaran agama dengan penganutnya. Ketika ajaran agama yang semula diserap langsung melalui pengalaman praktis mulai berubah menjadi teks, maka ketika itu sebuah jurang sudah mulai digali. Ketika al-Quran dan hadis berubah menjadi teks formal dan tertutup, ketika itu ia menjadi sebuah benda, yakni lembaran bahan tulis yang dicoretcoret dengan tinta hitam. Ia tidak lebih dari sebuah benda, jika ia tidak dibaca oleh umatnya.

Jurang tingkat kedua adalah jurang bahasa terutama bagi masyarakat Muslim non-Arab. Meskipun umat Islam begitu antusias membaca al-Quran setiap saat dan dalam berbagai kesempatan, tapi sayang kebanyakan mereka tidak lebih seperti seekor burung beo yang menyanyikan lagu Indonesia raya. Di sini jurang ini sulit terjembatani kecuali sebuah jembatan kecil melalui terjemahan.

\section{Penutup}

Dewasa ini Islam yang dipercaya sebagai rabmatan li l'âlamîn banyak dihujat akibat sebagian Muslim yang menampilkan keislamannya yang eksklusif, rasial, radikal, dan bahkan penyebar teror dan brutal. Jika semua sifat-sifat tersebut merupakan sebuah 
realita tentu saja hal itu bersumber dari pemahaman mereka terhadap agamanya yang gagal memahami agama dan Islam sebagai rahmatan li lâlamîn. dalam konteks kekinian. Tidak dapat disangkal lagi bahwa terbentuknya Islam dalam perjalanan sejarahnya telah melahirkan sebuah peradaban besar, terutama ketika ia dipahami sebagai sumber nilai yang mampu melayani dan berdampingan dengan peradaban lainnya. Dengan kata lain Muslim mampu menampilkan sisi-sisi universalisme nilai-nilai Islam itu.

Dalam konteks masa kini, yang perlu menjadi perhatian adalah: pertama, bagaimana mengembangkan minda yang terbuka (open mind) yang dapat menimbang, memilih, dan memilah berbagai entitas, realitas, dan gejala dalam dunia global saat ini. Kedua bagaimana menumbuhkan kemampuan kritik-diri (selfcritique) terhadap diri, tradisi (warâtsah), budaya, dan peradaban sendiri agar dapat mengukur dan menilai relevansi dan manfaatnya terhadap peradaban manusia pada masa sekarang dan masa depan tanpa kehilangan identitas. Dengan begitu kita dapat memelihara yang lama yang baik dan mengambil yang baru yang lebih baik. 


\section{DAFTAR PUSTAKA}

al-Ashfahâniy, Ar-Râghib., t.th, Mu jam Alfẫ̧ al-Qưrân al-Karim. Bayrût: Dâr al Fikr

al-`Asqalâniy, Ibn Hajar, t.th, Fath al-Bârî, I Riyâdl: al-Maktabaț asSalafiyah.

ath-Thabarsiy, Abû 'Alî al-Fadll ibn alHasan., 1986, Majma' alBayân, I Bayrût: Dâr Ihyầ' atTurâts al-`Arabiy

ath-Thabâtabâ'iy., Muhammad uusayn,. 1974., Al-Mĩzân fî Tafsîr alQur'ân, I Bayrût: Mu'assasat al-A 'lâm

al-Bukhâriy, Muhammad ibn Ismâ' ̂̂l., 1981., Shabîh al-Bukhâriy, Bayrût: Dâr al-Fikr

Cawidu, Harifuddin., 1991, Konsep Kufur dalam Al-Qur'an Jakarta: Bulan Bintang

Deconchy, Jean Pierre, 1970. "Milton Rokeach et la Notion de Dogmatisme", Archieves de Sociologie des Religions, 30,

Falk, Colin., 1989., Myth, Truth, and Literature: Toward a True Post-Modernism, Cambridge: Cambridge University Press.

Farsi., Nabih Amir dan Galdden, Harold W., 1960, "Tathawwur Ma 'nâ

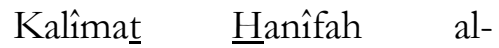

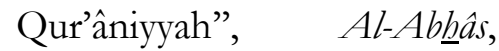
XIII, 1 al-Marâghiy, t.t.: t.p.

ibn Zakariyâ, Abû al- $\underline{H} a s a n$ Ahmad ibn Fâris., 1972., Mu jam Maqâyis al-Lughah, II. Kairo: Musthafâ al-Bâbiy al-ㅂalabiy wa Awlâduh

Lewis, Bernard., et al. (ed.), 1971., The Encyclopedia of Islam, II Leiden: E.J. Brill
Oosten, Jarich, 1985, “Cultural Anthropological Approaches", dalam Frank Whaling, Contemporary Approaches to the Study of Religion, Berlin: Walter de Gruyter \& Co.,.

Smith, Jane I. 1975., An Historical and Semantic Study of the Term 'Islam' as Seen in Sequence of Qur'an Commentaries Montana: Scholar Press for Harvard Theological Review 